\title{
Are the old International Board for Plant Genetic Resources (IBPGR) base collections available through the Plant Treaty's multilateral system of access and benefit sharing? A review
}

\author{
Imke Thormann $\mathbb{D} \cdot$ Johannes M. M. Engels $\cdot$ Michael Halewood
}

Received: 20 April 2018/ Accepted: 30 October 2018/Published online: 13 November 2018

(C) The Author(s) 2018

\begin{abstract}
In 1975, the International Board for Plant Genetic Resources created the first internationally linked system of genebanks, known as the Registry of Base Collections (RBC), to conserve plant germplasm and make it available globally for agricultural research and development. Over time, international efforts shifted away from enhancing and building the RBC toward other means to promote the conservation and sustainable use of plant genetic resources. Perhaps the most important development in this regard was the negotiation of the International Treaty on Plant Genetic Resources for Food and Agriculture (Plant Treaty or ITPGRFA) and the development of its multilateral system for access and benefit sharing (multilateral system). Our study aimed to ascertain whether the RBC materials are still being conserved/ curated in the original recipient organizations. We also sought to assess whether those materials have been included in, and are available through, the ITPGRFA's
\end{abstract}

Electronic supplementary material The online version of this article (https://doi.org/10.1007/s10722-018-0715-5) contains supplementary material, which is available to authorized users.

I. Thormann $(\bowtie) \cdot$ J. M. M. Engels $\cdot$ M. Halewood

Bioversity International, Rome, Italy

e-mail: imke.thormann@gmail.com

Present Address:

I. Thormann

Federal Office for Agriculture and Food, Bonn, Germany multilateral system. This outcome would be significant since, in many ways, the multilateral system reflects the spirit, commitment, and objectives of the RBC, with important additional components (e.g. obligations to share monetary benefits derived from the uses of plant genetic resources for food and agriculture). We identify four levels of probability that RBC materials are included in, and available through, the multilateral system. Ultimately, we find that there is a high level of probability that approximately $80 \%$ of the RBC materials are currently available through the multilateral system. We further identify a number of possible interventions that could be made to ensure that all RBC materials are conserved and made available through the multilateral system (or on similar terms and conditions of facilitated access and benefit sharing).

Keywords Access and benefit sharing - Global genebank system - International Treaty on Plant Genetic Resources for Food and Agriculture . Agricultural research and development $\cdot$ Network of base collections

\section{Introduction}

The International Board for Plant Genetic Resources (IBPGR) was created in 1974 to respond to concerns 
about the rapid loss of farmers' varieties and crop wild relatives, particularly in centres of crop diversity. This loss was mainly attributed to the introduction of improved high-yielding varieties (Frankel and Hawkes 1975; Harlan 1975). Between 1975 and 1995, the IBPGR supported the collecting of over 200,000 samples of threatened landraces, wild relatives and other materials in 136 countries. The IBPGR also coordinated the creation of an internationally linked system of genebanks known as the Registry of Base Collections (RBC) to conserve and make available a subset of those materials (Hansen et al. 1984).

The IBPGR started the development of the RBC at the end of 1975 and signed the first agreement with the International Center for Tropical Agriculture (CIAT) for the establishment and conservation of a regional collection of Phaseolus L. The IBPGR worked in close collaboration with the United Nations Food and Agriculture Organization (FAO), which was the administrative host of the IBPGR at the time, establishing the RBC. One of the guiding principles and architectural pillars of the RBC was that selected genebanks around the world would accept responsibility for managing a regional or global base collection of a given crop, under well-defined storage conditions and infrastructure that would ensure long-term conservation. They also were required to make the conserved germplasm available upon request to any bona fide user. At the end of the 1990s, the RBC included 52 selected genebanks (Table 1) spread across all continents, covering 80 genera and a total of approximately 250 species (IBPGR 1991; Thormann et al. 2015). In total, the RBC collections included 144,000 accessions. ${ }^{1}$

Over time, international efforts shifted away from enhancing and building the RBC toward a focus on other, additional means to promote the conservation and sustainable use of plant genetic resources, with considerable efforts put into developing equitable benefit-sharing mechanisms. Perhaps the most important development in this regard has been the negotiation of the International Treaty on Plant Genetic Resources for Food and Agriculture (Plant Treaty or ITPGRFA), which came into force in 2004 (FAO 2009). Among

\footnotetext{
${ }^{1}$ These 144,000 accessions derive from about 98,000 collected samples. As the samples were distributed to more than one genebank, the number of accessions generated is higher than the number of samples collected.
}

other things, the ITPGRFA creates the multilateral system of access and benefit sharing (multilateral system), which is meant to provide a sound legal basis for the Contracting Parties and their constituents and international organizations to virtually pool and exchange plant genetic resource for food and agriculture (PGRFA) and share benefits derived from their use. The multilateral system embraces a number of the core principles and basic architecture of the RBC but goes further in important ways-for example, legally requiring PGRFA users to share monetary benefits under certain circumstances.

\section{Purpose of the study}

Thormann et al. (2015) conducted a study to ascertain whether the RBC materials still existed and were being conserved/curated in the original recipient collections. We use information collected as part of that earlier study to make a preliminary assessment about which RBC materials have ultimately ended up in the ITPGRFA's multilateral system. The results of that latter assessment are reported in this article. Based on the results of this analysis, we were able to identify potential initiatives-involving cooperation between collection-hosting organizations, national governments, international agricultural research organizations, the Global Crop Diversity Trust, and the Secretariat of the ITPGRFA - to ensure that all of the RBC collections are ultimately available globally and publicly, as they were always meant to be, under the framework of the ITPGRFA.

International policy developments between the early days of the RBC and the ITPGRFA

In its earliest days of operation, the IBPGR, in close consultation with its Board of Trustees and FAO, invited and designated genebanks to become part of the RBC, beginning in 1975, in the absence of any other international mechanism. Not surprisingly, efforts to create the first ever internationally linked system of plant genetic resources collections in the form of the RBC attracted considerable critical attention, including questions about appropriate forms of governance of the network. For example, public controversy was generated when it was learned that RBC materials conserved at the National Seed Storage 
Table 1 Country, name and institute code of the genebanks belonging to the Register of base collections. In addition we provide the level of collection and the date of the agreement, if known

\begin{tabular}{|c|c|c|c|c|c|}
\hline Country & $\begin{array}{l}\text { FAO } \\
\text { institute } \\
\text { code }\end{array}$ & Institute name & Genera/Species ${ }^{\mathrm{a}}$ & Type of collection & $\begin{array}{l}\text { Date of } \\
\text { agreement } \\
\text { (if } \\
\text { recorded) }\end{array}$ \\
\hline Argentina & ARG1342 & $\begin{array}{l}\text { Institute Nacional de Tecnologia } \\
\text { Agropecuaria (INTA) }\end{array}$ & Groundnut [Arachis] & Regional-South America & \\
\hline Australia & AUS001 & $\begin{array}{l}\text { Commonwealth Scientific and } \\
\text { Industrial Research } \\
\text { Organization (CSIRO) Division } \\
\text { of Plant Industry, Canberra }\end{array}$ & $\begin{array}{l}\text { Wild perennial soybean } \\
\text { [Glycine }]\end{array}$ & Global & Mar-84 \\
\hline Australia & AUS045 & $\begin{array}{l}\text { Commonwealth Scientific and } \\
\text { Industrial Research } \\
\text { Organization (CSIRO) Division } \\
\text { of Tropical Crops \& Pastures. } \\
\text { Brisbane }\end{array}$ & $\begin{array}{l}\text { Cenchrus } \\
\text { Centrosema } \\
\text { Desmanthus } \\
\text { Desmodium } \\
\text { Digitaria } \\
\text { Macroptilium } \\
\text { Stylosanthes } \\
\text { Urochloa }\end{array}$ & $\begin{array}{l}\text { Global } \\
\text { Global } \\
\text { Global } \\
\text { Global } \\
\text { Global } \\
\text { Global } \\
\text { Global } \\
\text { Global }\end{array}$ & $\begin{array}{l}\text { May-86 } \\
\text { May-86 } \\
\text { May-86 } \\
\text { May-86 } \\
\text { May-86 } \\
\text { May-86 } \\
\text { May-86 } \\
\text { May-86 }\end{array}$ \\
\hline Bangladesh & BGD001 & $\begin{array}{l}\text { Bangladesh Jute Research } \\
\text { Institute (BJRI) }\end{array}$ & $\begin{array}{l}\text { Jute [Corchorus] } \\
\text { Kenaf [Hibiscus] }\end{array}$ & $\begin{array}{l}\text { Global } \\
\text { Global }\end{array}$ & $\begin{array}{l}\text { Apr-88 } \\
\text { Apr-88 }\end{array}$ \\
\hline Belgium & BEL014 & $\begin{array}{l}\text { Jardin Botanique National de } \\
\text { Belgique (JBNB) }\end{array}$ & $\begin{array}{l}\text { Wild Phaseolus } \\
\text { Wild Vigna }\end{array}$ & $\begin{array}{l}\text { Global } \\
\text { Global }\end{array}$ & $\begin{array}{l}\text { Dec-88 } \\
\text { Dec-88 }\end{array}$ \\
\hline Brazil & BRA003 & $\begin{array}{l}\text { Centro Nac de Recursos } \\
\text { Geneticos/Empresa Brasileira } \\
\text { de Pesquisa Agropecuaria } \\
\text { (CENARGEN/EMBRAPA) }\end{array}$ & $\begin{array}{l}\text { Wild Arachis } \\
\text { Macroptilium } \\
\text { Citrus }\end{array}$ & $\begin{array}{l}\text { Regional } \\
\text { Global } \\
\text { Regional }\end{array}$ & $\begin{array}{l}\text { Feb-84 } \\
\text { May-85 }\end{array}$ \\
\hline Canada & CAN004 & $\begin{array}{l}\text { Plant Gene Resources of Canada } \\
\text { (PGRC) }\end{array}$ & $\begin{array}{l}\text { Oats [Avena] } \\
\text { Barley [Hordeum] } \\
\text { Pennisetum } \\
\text { Brassica campestris, } \\
\text { B. juncea, } \\
\text { B. napus, } \\
\text { Sinapis alba }\end{array}$ & $\begin{array}{l}\text { Global } \\
\text { Global } \\
\text { Global } \\
\text { Global } \\
\text { Global } \\
\text { Global } \\
\text { Global }\end{array}$ & $\begin{array}{l}\text { Aug-77 } \\
\text { May-81 } \\
\text { Dec-80 } \\
\text { May-81 } \\
\text { May-81 } \\
\text { May-81 } \\
\text { May-81 }\end{array}$ \\
\hline Taiwan & TWN001 & $\begin{array}{l}\text { The World Vegetables Center } \\
\text { (AVRDC) }\end{array}$ & $\begin{array}{l}\text { Vigna radiata } \\
\text { Capsicum } \\
\text { Solanum melongena } \\
\text { Allium } \\
\text { Sweet potato) } \\
\quad \text { Ipomoea] }\end{array}$ & $\begin{array}{l}\text { Global } \\
\text { Global } \\
\text { Global } \\
\text { Global } \\
\text { Regional-Asia }\end{array}$ & Apr-84 \\
\hline $\begin{array}{l}\text { Republic of } \\
\text { China }\end{array}$ & CHN001 & $\begin{array}{l}\text { Chinese Academy of Agricultural } \\
\text { Sciences (CAAS) }\end{array}$ & $\begin{array}{l}\text { Wheat }[\text { Triticum }] \\
\text { Brassica oleracea } \\
\text { Raphanus }\end{array}$ & $\begin{array}{l}\text { Regional } \\
\text { Global } \\
\text { Global }\end{array}$ & $\begin{array}{l}\text { Mar-87 } \\
\text { Mar-87 } \\
\text { Mar-87 }\end{array}$ \\
\hline
\end{tabular}


Table 1 continued

\begin{tabular}{|c|c|c|c|c|c|}
\hline Country & $\begin{array}{l}\text { FAO } \\
\text { institute } \\
\text { code }\end{array}$ & Institute name & Genera/Species ${ }^{\mathrm{a}}$ & Type of collection & $\begin{array}{l}\text { Date of } \\
\text { agreement } \\
\text { (if } \\
\text { recorded) }\end{array}$ \\
\hline \multirow[t]{23}{*}{ Colombia } & \multirow[t]{23}{*}{ COL003 } & \multirow[t]{23}{*}{$\begin{array}{l}\text { Centro International de } \\
\text { Agricultura Tropical (CIAT) }\end{array}$} & $\begin{array}{l}\text { Phaseolus vulgaris wild } \\
\text { \& cult. }\end{array}$ & Regional-New World & Dec-75 \\
\hline & & & P. lunatus wild \& cult. & Regional-New World & Dec-76 \\
\hline & & & $\begin{array}{l}\text { P. coccineus wild \& } \\
\text { cult. }\end{array}$ & Regional-New World & Dec-76 \\
\hline & & & $\begin{array}{l}P . \text { acutifolius wild \& } \\
\text { cult. }\end{array}$ & Regional-New World & Dec-76 \\
\hline & & & $\begin{array}{l}\text { Cassava [Manihot } \\
\text { esculenta] }\end{array}$ & Global & Dec-83 \\
\hline & & & $\begin{array}{l}\text { Centrosema } \\
\text { brasilianum }\end{array}$ & Global & Jul-86 \\
\hline & & & C. macrocarpum & Global & Jul-86 \\
\hline & & & C. pubescens & Global & Jul-86 \\
\hline & & & Desmodium ovalifolium & Global & Jul-86 \\
\hline & & & D. heterophyllum & Global & Jul-86 \\
\hline & & & Pueraria phaseoloides & Global & Jul-86 \\
\hline & & & Stylosanthes capitata & Global & Jul-86 \\
\hline & & & S. macrocephala & Global & Jul-86 \\
\hline & & & S. guianensis & Global & Jul-86 \\
\hline & & & Zornia glabra & Global & Jul-86 \\
\hline & & & Andropogon gayanus & Global & Jul-86 \\
\hline & & & Brachiaria brizantha & Global & Jul-86 \\
\hline & & & B. decumbens & Global & Jul-86 \\
\hline & & & B. dictyoneura & Global & Jul-86 \\
\hline & & & B. humidiocola & Global & Jul-86 \\
\hline & & & B. ruziziensis & Global & Jul-86 \\
\hline & & & Hyparrhenia ruffa & Global & Jul-86 \\
\hline & & & Panicum maximum & Global & Jul-86 \\
\hline \multirow[t]{3}{*}{ Costa Rica } & \multirow[t]{3}{*}{ CRI001 } & \multirow{3}{*}{$\begin{array}{l}\text { Centro Agronomico Tropical de } \\
\text { Investigacion y Ensenanza } \\
\text { (CATIE) }\end{array}$} & Capsicum & Global & Apr-81 \\
\hline & & & Lycopersicon & Global & \\
\hline & & & Cocoa & Global & Sep-84 \\
\hline \multirow[t]{2}{*}{$\begin{array}{l}\text { Czech } \\
\text { Republic }\end{array}$} & \multirow[t]{2}{*}{ CZE003 } & \multirow[t]{2}{*}{$\begin{array}{l}\text { Research Institute for Plant } \\
\text { Production }\end{array}$} & Helianthus & $\begin{array}{l}\text { Regional-Europe } \\
\quad+\text { Mediterranean }\end{array}$ & Feb-89 \\
\hline & & & Allium & Global (field genebank) & Apr-85 \\
\hline \multirow[t]{5}{*}{ Ethiopia } & \multirow[t]{5}{*}{ ETH085 } & \multirow[t]{5}{*}{$\begin{array}{l}\text { Institute of Biodiversity } \\
\text { Conservation (PGRC/E) }\end{array}$} & $\begin{array}{l}\text { Indigenous Ethiopian } \\
\text { millets }\end{array}$ & Regional & Dec-76 \\
\hline & & & Barley [Hordeum] & Regional & Dec-81 \\
\hline & & & Brassica carinata & Global & Dec-81 \\
\hline & & & Eleusine & Global & Dec-81 \\
\hline & & & Eragrostis & Global & Dec-81 \\
\hline
\end{tabular}


Table 1 continued

\begin{tabular}{|c|c|c|c|c|c|}
\hline Country & $\begin{array}{l}\text { FAO } \\
\text { institute } \\
\text { code }\end{array}$ & Institute name & Genera/Species ${ }^{\mathrm{a}}$ & Type of collection & $\begin{array}{l}\text { Date of } \\
\text { agreement } \\
\text { (if } \\
\text { recorded) }\end{array}$ \\
\hline \multirow[t]{5}{*}{ Ethiopia } & \multirow[t]{5}{*}{ ETH013 } & \multirow{5}{*}{$\begin{array}{l}\text { International Livestock Research } \\
\text { Institute (ILRI) }\end{array}$} & Neonotonia & Regional-African & Apr-86 \\
\hline & & & Trifolium & Regional-African & Apr-86 \\
\hline & & & Cenchrus & Global & Apr-86 \\
\hline & & & Digitaria & Global & Apr-86 \\
\hline & & & Lotononis & Global & Apr-86 \\
\hline France & FRA006 & $\begin{array}{l}\text { Département des Productions } \\
\text { Fruitières et Horticoles (INRA- } \\
\text { CIRAD) (CIRAD-FLHOR) }\end{array}$ & $\begin{array}{l}\text { Citrus and related } \\
\text { species }\end{array}$ & $\begin{array}{l}\text { Regional- } \\
\text { Mediterranean }+ \text { Africa } \\
\text { field genebank }\end{array}$ & Jun-87 \\
\hline France & FRA002 & $\begin{array}{l}\text { Department des cultures } \\
\text { annuelles (CIRAD-CA) }\end{array}$ & Gossypium & Global & \\
\hline \multirow[t]{2}{*}{ Germany } & \multirow[t]{2}{*}{ DEU146 } & \multirow{2}{*}{$\begin{array}{l}\text { Leibniz Institute of Plant } \\
\text { Genetics and Crop Plant } \\
\text { Research (IPK) }\end{array}$} & Lycopersicon & Global & Jan-90 \\
\hline & & & Lupinus & Global & Jan-84 \\
\hline \multirow[t]{8}{*}{ Germany ${ }^{\mathrm{b}}$} & \multirow[t]{8}{*}{$\mathrm{DEU}^{\mathrm{b}}$} & \multirow{8}{*}{$\begin{array}{l}\text { FAL Institute of Crop Science } \\
\text { and Plant Breeding }\end{array}$} & Avena & Global & Oct-89 \\
\hline & & & Beta & Global & Mar-77 \\
\hline & & & Brassica carinata & Global & Apr-81 \\
\hline & & & B. campestris & Global & Apr-81 \\
\hline & & & B. juncea & Global & Apr-81 \\
\hline & & & B. napus & Global & Apr-81 \\
\hline & & & Sinapis & Global & Apr-81 \\
\hline & & & Phaseolus & Regional-Europe & Feb-85 \\
\hline \multirow[t]{3}{*}{ Greece } & \multirow[t]{3}{*}{ GRC005 } & \multirow[t]{3}{*}{ Greek Gene Bank } & Gossypium & $\begin{array}{l}\text { Regional-South Europe- } \\
\text { Mediterranean }\end{array}$ & Apr-84 \\
\hline & & & Tobacco & $\begin{array}{l}\text { Regional-South Europe- } \\
\text { Mediterranean }\end{array}$ & Apr-84 \\
\hline & & & Beta & $\begin{array}{l}\text { Regional-South Europe- } \\
\text { Mediterranean }\end{array}$ & Apr-84 \\
\hline \multirow[t]{2}{*}{ Hungary } & \multirow[t]{2}{*}{ HUN003 } & \multirow[t]{2}{*}{$\begin{array}{l}\text { Research Centre for } \\
\text { Agrobiodiversity (RCA) }\end{array}$} & Allium ampeloprasum & $\begin{array}{l}\text { Regional-South }+ \text { East } \\
\text { Europe }\end{array}$ & Nov-84 \\
\hline & & & Allium cepa & $\begin{array}{l}\text { Regional-South }+ \text { East } \\
\text { Europe }\end{array}$ & Nov-84 \\
\hline \multirow[t]{13}{*}{ India } & \multirow[t]{13}{*}{ IND001 } & \multirow{13}{*}{$\begin{array}{l}\text { National Bureau of Plant Genetic } \\
\text { Resources (NBPGR) }\end{array}$} & Vigna mungo & Global & Nov-87 \\
\hline & & & Vigna umbellata & Global & Nov-87 \\
\hline & & & Capsicum & Regional-Asian & Nov-87 \\
\hline & & & Brassica juncea & Regional-Asian & Nov-87 \\
\hline & & & B. campestris & Regional-Asian & Nov-87 \\
\hline & & & Raphanus & Regional & Nov-87 \\
\hline & & & Okra [Abelsmoschus] & Global & Nov-87 \\
\hline & & & Lablab purpureus & Global & Nov-87 \\
\hline & & & Cajanus cajan & Global & Nov-87 \\
\hline & & & Carthamus tinctorius & Global & Nov-87 \\
\hline & & & Solanum melongena & Global & Nov-87 \\
\hline & & & Amaranthus & Regional-Asian & Feb-81 \\
\hline & & & Minor Indian millets* & Regional-Asian & Aug-77 \\
\hline
\end{tabular}


Table 1 continued

\begin{tabular}{|c|c|c|c|c|c|}
\hline Country & $\begin{array}{l}\text { FAO } \\
\text { institute } \\
\text { code }\end{array}$ & Institute name & Genera/Species ${ }^{\mathrm{a}}$ & Type of collection & $\begin{array}{l}\text { Date of } \\
\text { agreement } \\
\text { (if } \\
\text { recorded) }\end{array}$ \\
\hline India & IND012 & Sugarcane Breeding Institute & Sugarcane [Saccharum] & Global (field genebank) & Jan-88 \\
\hline \multirow[t]{8}{*}{ India } & \multirow[t]{8}{*}{ IND002 } & \multirow{8}{*}{$\begin{array}{l}\text { International Crop Research } \\
\text { Institute for the Semi-Arid } \\
\text { Tropics (ICRISAT) }\end{array}$} & Pennisetum & Global & \\
\hline & & & $\begin{array}{l}\text { Sorghum (cultivated and } \\
\text { wild) }\end{array}$ & Global & Jul-84 \\
\hline & & & Eleusine & Global & Jul-84 \\
\hline & & & Setaria italica & Global & Jul-84 \\
\hline & & & Panicum milaceum & Global & Jul-84 \\
\hline & & & Chickpea & Global & Jul-84 \\
\hline & & & Pigeonpea & Global & Jul-84 \\
\hline & & & Groundnut [Arachis] & Global & Jul-84 \\
\hline Italy & ITA004 & Istituto di Genetica Vegetale & Triticum & Global & May-77 \\
\hline Jamaica & JAM003 & $\begin{array}{l}\text { Banana Board Research } \\
\text { Department }\end{array}$ & $\begin{array}{l}\text { Musa (wild and cult., } \\
\text { including banana, } \\
\text { plantain + wild } \\
\text { relatives) }\end{array}$ & Regional (field genebank) & Dec-86 \\
\hline \multirow[t]{12}{*}{ Japan } & \multirow[t]{12}{*}{ JPN003 } & \multirow{12}{*}{$\begin{array}{l}\text { National Institute of } \\
\text { Agrobiological Science (NIAS) }\end{array}$} & Oryza sativa & Global & Dec-76 \\
\hline & & & Maize $[Z e a]$ & Regional-Asian & Sep-85 \\
\hline & & & Wheat [Triticum] & Global & Sep-85 \\
\hline & & & Barley [Hordeum] & Regional-Asian & Sep-85 \\
\hline & & & $\begin{array}{l}\text { Sweet potato seed } \\
\text { [Ipomoea] }\end{array}$ & Global & Sep-85 \\
\hline & & & Cruciferous crops & Regional-East Asian & Sep-85 \\
\hline & & & Allium & Asian & Sep-85 \\
\hline & & & $\begin{array}{l}\text { Sugarcane seed } \\
\text { [Ipomoea }]\end{array}$ & Global & Sep-85 \\
\hline & & & Vigna angularis & Global & Sep-85 \\
\hline & & & Glycine max & Global & Sep-85 \\
\hline & & & Panicum & Global & Sep-85 \\
\hline & & & Chloris & Global & Sep-85 \\
\hline Japan & JPN059 & $\begin{array}{l}\text { Faculty of Agriculture, Tohoku } \\
\text { University }\end{array}$ & Wild cruciferous crops & Global & Jul-81 \\
\hline Japan & JPN001 & $\begin{array}{l}\text { Plant Germplasm Institute, } \\
\text { Faculty of Agriculture, Kyoto } \\
\text { University }\end{array}$ & $\begin{array}{l}\text { Wheat including } \\
\text { Triticum and Aegilops }\end{array}$ & Global & Jan-77 \\
\hline Japan & JPN004 & Fruit Tree Research Station & Citrus and relatives & Regional (field genebank) & Sep-85 \\
\hline Kenya & KEN007 & $\begin{array}{l}\text { Kenya Agricultural Research } \\
\text { Institute (KARI) }\end{array}$ & Sesame $[$ Sesamum $]$ & Global & Jan-90 \\
\hline $\begin{array}{l}\text { Republic of } \\
\text { Korea }\end{array}$ & KOR010 & $\begin{array}{l}\text { Rural Development } \\
\text { Administration (RDA) }\end{array}$ & Sesame $[$ Sesamum] & Global & Mar-89 \\
\hline Malaysia & MYS030 & University of Malaya & Citrus & Global (field genebank) & Dec-86 \\
\hline Mexico & MEX001 & $\begin{array}{l}\text { Estación de Iguala, Instituto } \\
\text { Nacional de Investigaciones } \\
\text { Agrícolas (INIA) }\end{array}$ & $\begin{array}{l}\text { Cassava }[\text { Manihot } \\
\text { esculenta }]+ \text { wild } \\
\text { relatives }\end{array}$ & $\begin{array}{l}\text { Regional- Central America } \\
\text { (field genebank) }\end{array}$ & Jun-84 \\
\hline
\end{tabular}


Table 1 continued

\begin{tabular}{|c|c|c|c|c|c|}
\hline Country & $\begin{array}{l}\text { FAO } \\
\text { institute } \\
\text { code }\end{array}$ & Institute name & Genera/Species ${ }^{\mathrm{a}}$ & Type of collection & $\begin{array}{l}\text { Date of } \\
\text { agreement } \\
\text { (if } \\
\text { recorded) }\end{array}$ \\
\hline Mexico & MEX002 & $\begin{array}{l}\text { Centro International de } \\
\text { Mejoramento de Maiz y Trigo } \\
\text { (CIMMYT) }\end{array}$ & $\begin{array}{l}\text { Maize }[\text { Zea }] \\
\text { Wheat }[\text { Triticum }] \\
\text { Triticale [Triticosecale }]\end{array}$ & $\begin{array}{l}\text { Global } \\
\text { Global } \\
\text { Global }\end{array}$ & $\begin{array}{l}\text { Jun-90 } \\
\text { Jun-90 } \\
\text { Jun-90 }\end{array}$ \\
\hline $\begin{array}{l}\text { The } \\
\text { Netherlands }\end{array}$ & NLD037 & $\begin{array}{l}\text { Center for Genetic Resources } \\
\text { (CGN) }\end{array}$ & $\begin{array}{l}\text { Lettuce [Lactuca] } \\
\text { Allium cepa } \\
\text { Allium ampeloprasum } \\
\text { Wild Allium species } \\
\text { Capsicum } \\
\text { Brassica oleracea } \\
\text { Solanum melongena }\end{array}$ & $\begin{array}{l}\text { Global } \\
\text { Global } \\
\text { Global } \\
\text { Global } \\
\text { Global } \\
\text { Global } \\
\text { Global }\end{array}$ & $\begin{array}{l}\text { Feb-89 } \\
\text { Mar-86 } \\
\text { Mar-86 } \\
\text { Mar-86 } \\
\text { Jul-81 } \\
\text { Jul-81 } \\
\text { Jul-81 }\end{array}$ \\
\hline Nigeria & NGA039 & $\begin{array}{l}\text { International Institute of Tropival } \\
\text { Agriculture (IITA) }\end{array}$ & $\begin{array}{l}\text { Cowpea [Vigna } \\
\text { unguiculata] } \\
\text { Cassava }[\text { Manihot } \\
\text { esculenta] + wild } \\
\text { spp. } \\
\text { Rice }[\text { Oryza] }\end{array}$ & Regional-African & Jun-84 \\
\hline Peru & PER001 & $\begin{array}{l}\text { Centro Internacional de la Papa } \\
\text { (CIP) }\end{array}$ & $\begin{array}{l}\text { Potato [Solanum } \\
\text { tuberosum] } \\
\text { Sweet potato [Ipomoea] }\end{array}$ & $\begin{array}{l}\text { Global } \\
\text { Global }\end{array}$ & $\begin{array}{l}\text { May-80 } \\
\text { No letter }\end{array}$ \\
\hline Philippines & PHL130 & Institute of Plant Breeding (IPB) & $\begin{array}{l}\text { Winged bean } \\
\text { [Psophocarpus } \\
\text { tetragonolobus] }\end{array}$ & Global & Dec-80 \\
\hline & & & Lycopersicon & Regional-Asian & May-81 \\
\hline & & & & Global & $\begin{array}{l}\text { Dec-83 } \\
\text { Dec-83 }\end{array}$ \\
\hline & & & $\begin{array}{l}\text { Luffa } \\
\text { Momordica } \\
\text { Trichosanthes } \\
\text { Vigna radiata }\end{array}$ & $\begin{array}{l}\text { Global } \\
\text { Global } \\
\text { Global } \\
\text { Global }\end{array}$ & $\begin{array}{l}\text { Dec-83 } \\
\text { Dec-83 } \\
\text { Dec-83 } \\
\text { Dec-83 }\end{array}$ \\
\hline Philippines & PHL150 & $\begin{array}{l}\text { Philippine Council for } \\
\text { Agricultural and Resources } \\
\text { Research \& Development } \\
\text { (PCARRD) }\end{array}$ & $\begin{array}{l}\text { Banana, plantain and } \\
\text { wild relatives [Musa] }\end{array}$ & $\begin{array}{l}\text { Regional-Asian (field } \\
\text { genebank) }\end{array}$ & Jun-84 \\
\hline Philippines & PHL001 & $\begin{array}{l}\text { International Rice Research } \\
\text { Institute (IRRI) }\end{array}$ & $\begin{array}{l}\text { Oryza sativa (indica \& } \\
\text { javanica) } \\
\text { Wild Oryza }\end{array}$ & $\begin{array}{l}\text { Global } \\
\text { Global }\end{array}$ & Dec-76 \\
\hline Poland & POL003 & Polish Gene Bank & Pisum & $\begin{array}{l}\text { Regional-Central + East } \\
\text { Europe }\end{array}$ & Jan-84 \\
\hline & & & Rye $[$ Secale $]$ & Global & Feb-83 \\
\hline Portugal & PRT005 & Portuguese Gene Bank & Maize $[Z e a]$ & Regional-South Europe & Jul-80 \\
\hline
\end{tabular}


Table 1 continued

\begin{tabular}{|c|c|c|c|c|c|}
\hline Country & $\begin{array}{l}\text { FAO } \\
\text { institute } \\
\text { code }\end{array}$ & Institute name & Genera/Species ${ }^{\mathrm{a}}$ & Type of collection & $\begin{array}{l}\text { Date of } \\
\text { agreement } \\
\text { (if } \\
\text { recorded) }\end{array}$ \\
\hline \multirow[t]{5}{*}{ Russia } & \multirow[t]{5}{*}{ RUS001 } & \multirow{5}{*}{$\begin{array}{l}\text { Vavilov Institute of Plant } \\
\text { Industry }\end{array}$} & Maize $[Z e a]$ & Regional-European & Jun-88 \\
\hline & & & Cucurbita & Global & Jun-88 \\
\hline & & & Triticum & Global & Jun-88 \\
\hline & & & Cucumis & Global & Jun-88 \\
\hline & & & Citrullus & Global & Jun-88 \\
\hline Spain & ESP085 & $\begin{array}{l}\text { Universidad Politecnica de } \\
\text { Madrid }\end{array}$ & $\begin{array}{l}\text { Wild relatives of } \\
\text { cruciferous crops }\end{array}$ & Global & Apr-81 \\
\hline \multirow[t]{3}{*}{ Spain } & \multirow[t]{3}{*}{ ESP002 } & \multirow{3}{*}{$\begin{array}{l}\text { Instituto Nacional de } \\
\text { Investigaciones Agrarias } \\
\text { (INIA) }\end{array}$} & Citrus \& wild species & $\begin{array}{l}\text { Regional-Mediterranean } \\
\text { (field genebank) }\end{array}$ & Aug-84 \\
\hline & & & Cucumis & Global & Jan-84 \\
\hline & & & Citrullus & Global & Jan-84 \\
\hline \multirow[t]{5}{*}{ Sweden } & \multirow[t]{5}{*}{ SWE054 } & \multirow{5}{*}{$\begin{array}{l}\text { Nordic Genetic Resources Centre } \\
\text { (NordGen) }\end{array}$} & Pisum & Global & 1981 \\
\hline & & & Hordeum & Regional-European & 1981 \\
\hline & & & Avena & Global & 1981 \\
\hline & & & Secale & Global & 1981 \\
\hline & & & Beta & Global & 1981 \\
\hline \multirow[t]{7}{*}{ Syria } & \multirow[t]{7}{*}{ SYR002 } & \multirow{7}{*}{$\begin{array}{l}\text { International Centre for } \\
\text { Agricultural Research in the } \\
\text { Dry Areas (ICARDA) }\end{array}$} & $\begin{array}{l}\text { Kabuli chickpea }[\text { Cicer } \\
\text { arietinum }]\end{array}$ & Global & Jan-89 \\
\hline & & & Faba bean [Vicia] & Global & Jan-89 \\
\hline & & & Lentil $[$ Lens] & Global & Jan-89 \\
\hline & & & Barley [Hordeum] & Global & Jan-89 \\
\hline & & & Durum wheat [Triticum] & Global & Jan-89 \\
\hline & & & $\begin{array}{l}\text { Wild progenitors of } \\
\text { wheat }\end{array}$ & Global & Jan-89 \\
\hline & & & Medicago- annual & Global & Sep-90 \\
\hline \multirow[t]{2}{*}{ Thailand } & \multirow[t]{2}{*}{ THA006 } & \multirow[t]{2}{*}{$\begin{array}{l}\text { Thailand Institute of Scientific } \\
\text { and Technological Research } \\
\text { (TISTR) }\end{array}$} & $\begin{array}{l}\text { Winged bean } \\
\text { [Psophocarpus } \\
\text { tetragonolobus }]\end{array}$ & Global & Jun-84 \\
\hline & & & Maize $[Z e a]$ & Regional-Asian & Jun-84 \\
\hline $\begin{array}{l}\text { Trinidad and } \\
\text { Tobago }\end{array}$ & TTO001 & University of the West Indies & $\begin{array}{l}\text { Cocoa and related } \\
\text { species [Herrania and } \\
\text { Theobroma] }\end{array}$ & Global (field genebank) & Aug-84 \\
\hline \multirow[t]{6}{*}{$\begin{array}{l}\text { United } \\
\text { Kingdom }\end{array}$} & \multirow[t]{6}{*}{ GBR004 } & \multirow[t]{6}{*}{$\begin{array}{l}\text { Royal Botanic Gardens Kew, } \\
\text { Seed Bank }\end{array}$} & $\begin{array}{l}\text { Woody species (of } \\
\text { interest for fuel wood) }\end{array}$ & Global-(Arid zones) & Jan-83 \\
\hline & & & Neonotonia & Regional-African & Mar-85 \\
\hline & & & Trifolium & Regional-African & Mar-85 \\
\hline & & & Cenchrus & Global & Mar-85 \\
\hline & & & Digitaria & Global & Mar-85 \\
\hline & & & Lotononis & Global & Mar-85 \\
\hline
\end{tabular}


Table 1 continued

\begin{tabular}{|c|c|c|c|c|c|}
\hline Country & $\begin{array}{l}\text { FAO } \\
\text { institute } \\
\text { code }\end{array}$ & Institute name & Genera/Species ${ }^{\mathrm{a}}$ & Type of collection & $\begin{array}{l}\text { Date of } \\
\text { agreement } \\
\text { (if } \\
\text { recorded) }\end{array}$ \\
\hline \multirow{8}{*}{$\begin{array}{l}\text { United } \\
\text { Kingdom }\end{array}$} & \multirow[t]{8}{*}{ GBR006 } & \multirow[t]{8}{*}{ Warwick Genetic Resources Unit } & Carrot [Daucus] & Global & May-89 \\
\hline & & & Brassica oleracea & Global & Nov-81 \\
\hline & & & B. campestris & Global & Nov-81 \\
\hline & & & B. juncea & Global & Nov-81 \\
\hline & & & B. napus & Global & Nov-81 \\
\hline & & & Raphanus & Global & Nov-81 \\
\hline & & & Allium & Global & Nov-81 \\
\hline & & & Beta & Regional-European & Nov-81 \\
\hline \multirow[t]{25}{*}{ USA } & \multirow[t]{25}{*}{ USA } & \multirow{25}{*}{$\begin{array}{l}\text { USDA National Plant } \\
\text { Germplasm System (NPGS) }\end{array}$} & Wheat [Triticum] & Global & Jan-77 \\
\hline & & & Sorghum & Global & Jan-77 \\
\hline & & & Pennisetum (crop) & Global & Jan-77 \\
\hline & & & Phaseolus & Global & Jan-79 \\
\hline & & & Amaranthus & Global & Jun-80 \\
\hline & & & Lycopersicon & Global & Apr-81 \\
\hline & & & Solanum melongena & Regional—New World & Apr-81 \\
\hline & & & Sugarcane [Saccharum] & Global (field genebank) & Jun-83 \\
\hline & & & Cucurbita & Global & Dec-83 \\
\hline & & & Cucumis & Global & Dec-83 \\
\hline & & & Citrullus & Global & Dec-83 \\
\hline & & & Glycine max & Global & Dec-83 \\
\hline & & & Citrus \& relatives & Regional (field genebank) & Aug-84 \\
\hline & & & Leucaena & Global & Apr-85 \\
\hline & & & Zornia & Global & Apr-85 \\
\hline & & & Paspalum & Global & Apr-85 \\
\hline & & & Cynodon & Global & Apr-85 \\
\hline & & & Pennisetum (forage) & Global & Apr-85 \\
\hline & & & Rice $[$ Oryza] & $\begin{array}{l}\text { Regional- Mediterranean, } \\
\text { USA, South America }\end{array}$ & Jan-83 \\
\hline & & & Maize $[Z e a]$ & Global & Jan-83 \\
\hline & & & Vigna unguiculata & Global & \\
\hline & & & Allium сера \& wild spp. & Global & \\
\hline & & & Sweet potato [Ipomoea $]$ & Global (seeds) & \\
\hline & & & Abelmoschus & Global & \\
\hline & & & Sugarcane [Saccharum] & Global (seeds) & \\
\hline
\end{tabular}

Asterisk indicates Minor Indian millets include Panicum, Eleusine, Setaria, Echinochloa and Paspalum

${ }^{a}$ The genus name was added where only the common name was provided

${ }^{\mathrm{b}}$ This genebank does not exist anymore. Collections have been transferred to DEU146 
Laboratory in Fort Collins, United States, were considered to be the property of the United States and that the United States was not making RBC materials available to recipients in countries with whom it had poor relations (Kloppenburg and Kleinman 1987; Mooney 1983). This situation contributed to calls to 'replace the loose formality of IBPGR arrangements with legally binding agreements between FAO and participating institutions or preferably governments' (Frankel 1988).

In 1983, the FAO Conference created the Commission on Plant Genetic Resources as the first intergovernmental organization to deal with PGRFA. ${ }^{2}$ At the same conference, the International Undertaking (IU) was adopted as an instrument to 'ensure that plant genetic resources of economic and/or social interest, particularly for agriculture, will be explored, preserved and made available for plant breeding and scientific purposes' (FAO 1983). ${ }^{3}$ The principle on which the IU was originally based was that plant genetic resources were 'heritage of mankind' and should be freely available without restrictions for the benefit of present and future generations. In the years that followed, this concept was weakened through successive reinterpretations in the form of FAO Conference resolutions that recognized the primacy of plant breeders' rights in 1989 and national sovereignty in $1991 .^{4}$ The Convention on Biological Diversity (CBD), which came into force in 1993, underscores the sovereign rights of countries over their own genetic resources. In 1994, the FAO initiated renegotiations of the IU to bring it into harmony with the CBD, reflecting much more fully the concept of state sovereignty over PGRFA.

Article 7 of the IU provides for the development of a global PGRFA system that should include 'an international network of base collections in genebanks, under the auspices or the jurisdiction of FAO'. In 1989, the Commission on Genetic Resources for Food and Agriculture (CGRFA) called for the

\footnotetext{
${ }^{2}$ In 1995, when its mandate was expanded to include PGRFA beyond plants, including, for example livestock genetic resources, the Commission on Plant Genetic Resources was renamed the Commission on Genetic Resources for Food and Agriculture to reflect its broader mandate.

3 International Undertaking on Plant Genetic Resources for Food and Agriculture, 1983, http://www.fao.org/waicent/ faoinfo/agricult/cgrfa/IU.htm (accessed 5 January 2018).

4 See Resolution 4/89, 5/89 and 3/91.
}

development of the International Network of Ex Situ Collections as part of this global system. During the administrative separation of the IBPGR from the FAO and the establishment of the IPGRI as its successor, a Memorandum of Understanding on Programme Cooperation was concluded in September 1990 between the IBPGR and the FAO. It included an article on the intention to merge the IBPGR's RBC with the FAO's International Network of Ex Situ Collections. It was thought that overseeing a global network of ex situ collections would be much more in line with the responsibilities of an intergovernmental organization such as the FAO rather than an international organization such as the newly reconstituted IBPGR, which was then renamed the IPGRI.

Eventually, the International Network of Ex Situ Collections became a reality in October 1994, when 12 CGIAR centres signed agreements with the FAO, placing most of their collections (approximately 450,000 accessions) under the auspices of the FAO as part of this international network. In this way, the RBC collections maintained at the CGIAR genebanks-approximately $38 \%$ of the RBC materials distributed by IBPGR - became 'automatically' part of the FAO's International Network of Ex Situ Collections. A survey of national RBC genebanks in Europe in 1995 investigated their preparedness to place their RBC base collections under the auspices of the FAO as part of the International Network as in trust germplasm (Thormann and Engels 2001). The outcome of this inventory was inconclusive. Efforts to encourage countries to change the status of the RBC collections held in national genebanks were weak and countries did not evince much desire to do so on their own (personal communication of J.M.M. Engels, 2017). Efforts under the auspices of the CGRFA to develop model agreements under the IU for national collections were similarly not concluded, with the result that none of the collections in the national RBC genebanks were formally included in the International Network. Ultimately, efforts to develop these agreements were eclipsed by the renegotiations of the IU, leading to the adoption of the ITPGRFA in 2001 (Halewood 2010, 2015).

The ITPGRFA came into force in June 2004. As of November 2017, there are 144 Contracting Parties, including the European Union. There are also 17 Article 15 agreements between the ITPGRFA's Governing Body and international institutes placing 
their ex situ collections under the ITPGRFA framework. It is estimated that 2 million accessions of ex situ materials are available worldwide through the multilateral system. In the multilateral system's first 10 years of operation from 2007 to 2016, over 4 million PGRFA samples were distributed, using almost 60,000 Standard Material Transfer Agreements (SMTA) (ITPGRFA 2017). In total, 93\% of those transfers were from the CGIAR centres, of which approximately $85 \%$ were to recipients in developing countries and countries with economies in transition. The overwhelming majority of these recipients were public sector research and development organizations. All of the materials in the multilateral system are transferred under the SMTA. Requestors in Contracting Parties have the right of facilitated access to materials in the multilateral system to use them for 'utilization and conservation for research, breeding and training for food and agriculture provided that such purpose does not include chemical, pharmaceutical and/or other non-food/feed industrial uses' [Article 12.3(a) of the ITPGRFA]. Providers are required to distribute the materials for free or for minimum administrative costs.

\section{Materials and methods}

First, we analysed whether the materials originally distributed to the 52 genebanks as part of the RBC would currently be included in the multilateral system, assuming they have continued to be conserved by those genebanks. We used the IBPGR publications and organizational records to ascertain the scope of the materials included in the RBC as well as the conditions under which the organizations agreed to host and distribute those materials, and we compared those to the conditions and scope of the multilateral system. As part of the exercise of trying to verify whether the RBC materials were included in the multilateral system, we accessed the ITPGRFA website to verify which countries have ratified the Treaty and to access lists of ITPGRFA Annex 1 crop and forage collections that, based on information from countries and international organizations, are available according to the terms and conditions of the multilateral system. ${ }^{5} \mathrm{We}$ also looked

$\overline{5}$ ITPGRFA, http://www.planttreaty.org/ (accessed July 2017). for information about non-Annex 1 materials that are being made available under the same terms and conditions as the multilateral system (that is, using the SMTA) by either international institutions or other providers in the Contracting Parties. To ascertain whether or not other RBC materials have been made available (and, if so, under what conditions), we surveyed secondary literature, organizational websites, and accession-level databases; we also surveyed the organizations to whom the RBC materials were originally sent, as discussed in the following paragraph.

Second, we sought to verify whether the originally distributed RBC materials were actually still being conserved by those recipient genebanks and the conditions under which they were being made available. To do this, the authors sent questionnaires (provided in Online Resource 1) to the 52 genebanks as presented in Table 1 that had signed RBC agreements with the IBPGR. The authors also sent each genebank all of the available passport data on the RBC materials extracted from the Bioversity Collecting Database (BCD) of the IBPGR-coordinated collecting missions (Thormann et al. 2012; Gaisberger et al. 2013). This information served to support the genebanks identifying which materials in their genebanks were received from the IBPGR and subject to the RBC agreements. The genebanks were also asked to share, with the authors, their own passport information about the relevant materials. The surveyed genebanks and the research team used this shared data to identify and 'link' $25 \%$ of the materials originally collected under the auspices of the IBPGR as part of the RBC with the accessions currently included in the collections maintained by the genebanks surveyed. Further details about this linking exercise, as well as the potential uses of the linked materials, are described by Thormann and colleagues (2015). We then analysed whether these materials were available through the multilateral system.

Given existing gaps in the information recordsparticularly, the fact that, to date, only $25 \%$ of RBC materials have been linked to existing collections-it was not possible to establish with certainty what proportion of RBC materials are currently included in the multilateral system. Instead, we were limited to analysing levels of probability. The levels of probability that an RBC sample would be included in the 
multilateral system increase from 0 upwards if/when the sample is held by a genebank:

Level 0 In a country that has not ratified the ITPGRFA

Level 1 In a country that has ratified the ITPGRFA, but the materials are non-Annex 1

Level 2 In a country that has ratified the ITPGRFA, the material is Annex 1, but the country has not notified the ITPGRFA Secretary about inclusion of materials that are of the same genera as those included in the RBC

Level 3 In a country that has ratified the ITPGRFA, the material is Annex 1, and the country has notified the ITPGRFA Secretary about inclusion of materials that are of the same genera as those included in the RBC and by the same organization as received the RBC materials

Level 4 That belongs to a CGIAR centre or another international institution that has placed its collections in the multilateral system as per Article 15 of the ITPGRFA, or makes its collections available under the same conditions

Levels 3 and 4 are roughly equivalent in providing high levels of certainty that the materials concerned, assuming they still exist, will be available through the multilateral system. However, we are keeping them separate since the kinds of organizations holding the materials are different, as are their positions in the overall governance system of the ITPGRFA.

Our findings can therefore be presented at two levels: first, with respect to the likelihood of inclusion of all of the original RBC materials, assuming they still exist, and, second, with respect to the subset of 'linked' materials that we were able to confirm, with the limited resources at our disposal. (Note that, with more resources, it is highly likely that a much higher number of confirmed links could be made between the originally distributed RBC materials and the materials currently held in genebanks around the world. Indeed, further work on tracking down and linking RBC materials is one of the recommendations at the end of this article.)

\section{Results}

The scope of genera included in the RBC was broader

A major difference between the RBC and the multilateral system lies in the coverage of crop genera. The RBC had a much broader focus on crops, including industrial crops and neglected and underutilized crops. While a large part (77\%) of the Annex 1 crops was also included in the RBC, the RBC included an additional 31 crops (see Table 2 and Online Resources 2 and 3).

The scope of the RBC was extremely broad and potentially unlimited with respect to all cultivated species. It initially included seed propagated cereals, food legumes, vegetables, forages, fibre crops (for example, jute, kenaf), industrial crops (for example, sugarcane, cacao), and, in many cases, some of their wild relatives. In the later 1980s, the RBC's scope was expanded to also include field genebanks for Allium, banana, cacao, cassava, citrus, and sugarcane. Crop expert committees were involved in the selection of crops and genebanks. For the most part, practical and scientific considerations took precedence in deciding what genera should be included in the RBC.

The multilateral system includes a finite list of 64 crops and forage genera that are identified in Annex 1 of the ITPGRFA, including wild relatives if they are of the same genus/crop gene pool (unless they are explicitly excluded from the Annex 1 list). The criteria for including crops or forages in the multilateral system are 'food security and interdependence' (Article 11.1 of the ITPGRFA). ${ }^{6}$ Thus, crops that are not used for human food or animal feed were not included, ab initio. In addition, crops that may be important locally, but that are not widely used around the

\footnotetext{
${ }^{6}$ The criteria of interdependency reflects international recognition of the fact that no country is self-sufficient in terms of the genetic resources it needs to fulfill its food requirements, and countries have over time become more and more dependent on germplasm originally collected from other countries for their food and agricultural development (Flores-Palacios 1998; Ghimiray and Vernooy 2017; Khoury et al. 2015, 2016). All countries are dependent on plant genetic resources for food and agriculture (PGRFA) located or collected and conserved outside their own territory. It was shown that when provided with the opportunity of facilitated access, countries use a wide diversity of germplasm from many other countries, sub-regions and continents as inputs into their agricultural research and development programs (Galluzzi et al. 2016).
} 
Table 2 Number of crop and forage genera included in the RBC and in Annex 1 of the ITPGRFA

\begin{tabular}{llllll}
\hline & $\begin{array}{l}\text { Included in both the RBC } \\
\text { and Annex 1 }\end{array}$ & $\begin{array}{l}\text { Included in the } \\
\text { RBC only }\end{array}$ & $\begin{array}{l}\text { Included in } \\
\text { Annex 1 only }\end{array}$ & $\begin{array}{l}\text { Total number included } \\
\text { in the RBC }\end{array}$ & $\begin{array}{l}\text { Total number included } \\
\text { in Annex 1 }\end{array}$ \\
\hline Crops & 27 & 31 & 8 & 58 & 35 \\
Forages & 4 & 19 & 25 & 23 & 29 \\
\hline
\end{tabular}

world-so-called neglected and underutilized species-were also not included. ${ }^{7}$

While the multilateral system, sensu strictu, is limited to 64 crops and forages, it is important to note that the Governing Body of the ITPGRFA confirmed in 2009 that those international organizations that signed Article 15 agreements (placing their collections under the ITPGRFA's framework) should also distribute non-Annex 1 'in trust' materials using the same SMTA, thus de facto expanding the multilateral system to include distinct ex situ materials of nonAnnex 1 crops, held by international institutions. Furthermore, a number of countries-mainly in North America and Europe-have voluntarily adopted the policy to make a range of non-Annex 1 materials available using the SMTA, thereby exceeding their commitments under the ITPGRFA and de facto increasing the scope of crops and forages that can be accessed on the same terms and conditions as the multilateral system.

While the RBC was limited to ex situ collections, the multilateral system extends, at least in theory, to in situ PGRFA that are 'under the management and control of Contracting Parties and in the public domain' (Article 11.2 of the ITPGRFA). However, to date, there is very little information about how

\footnotetext{
${ }^{7}$ However, within these parameters, the actual composition of Annex 1 was subject to a highly politicized decision-making process, involving more than 150 countries negotiating the text of the ITPGRFA. This process has been described in length elsewhere (Khoury et al. 2015; Lim and Halewood 2008; Visser 2013). For now, it is perhaps enough to point out that the scope of crops and forages included in Annex 1 was motivated by concerns about food security but also highly influenced by political considerations that played out during the negotiations of the benefit-sharing provisions under the ITPGRFA. The potential scope of the list expanded and contracted dramatically over the course of the negotiations, with a number of crops being removed from the list in the final hours of negotiations. Notably, groundnut, tomato, sugar cane and oil palm are not included in Annex 1, despite their importance for food security.
}

countries are interpreting and implementing the relevant sections of the ITPGRFA in this regard.

The hosts/managers of materials included in the RBC and the multilateral system are similar

The kinds of organizations playing key roles in the conservation, use and sharing of genetic resources under both the RBC and the multilateral system are quite similar. All of the 52 genebanks hosting RBC collections were operated by national public or by international agricultural research and development organizations. The multilateral system automatically includes PGRFA of the Annex 1 crops and forages that are 'under the management and control of Contracting Parties and in the public domain' (Article 11.2 of the ITPGRFA) as well as those crops and forages managed by the international centres and available in the multilateral system through Article 15. For the most part, this formula will be interpreted in most countries to not automatically include materials controlled and managed by private companies, nongovernmental organizations, farmers' organizations, farmers, and provincial or municipal governments (Halewood et al. 2013; ITPGRFA 2015). In contrast, the formula will be interpreted to include materials controlled and managed de jure by national public organizations (Moore and Tymowski 2005).The ITPGRFA also recognizes the importance of additional materials being included in the multilateral system by natural and legal persons (including companies, non-governmental organizations, private universities, and so on), but recognizes such inclusion will need to be voluntary. Whether PGRFA may be automatically included in the multilateral system by virtue of being 'under the management and control' of national governments and 'in the public domain,' or voluntarily included by natural and legal persons, they are not practically available to anyone if information about their existence, and characteristics, is not 
published. The ITPGRFA does not explicitly require Contracting Parties to publish this information. However, in light of this important gap, the Treaty's Secretariat has circulated a request to all Contracting Parties to notify the Governing Body (through the Secretariat) about what collections are in the multilateral system. Interestingly, the model letter does not extend to information about in situ materials; perhaps that was considered too complex, given the long delays in getting responses from Contracting Parties about ex situ materials. To date, little information about the origin of the additional materials being voluntarily included in the multilateral system by natural and legal persons has been included in country reports to the Governing Body. The Governing Body of the ITPGRFA has repeatedly encouraged Contracting Parties to provide information about PGRFA that is available through the multilateral system.

Furthermore, the ITPGRFA also invites international institutions to sign agreements with the Governing Body of the Treaty, placing their materials under the ITPGRFA's framework (Article 15 of the ITPGRFA). To date, 17 international organizations have signed these agreements, 10 of which also previously received $\mathrm{RBC}$ materials. Thus, almost all of the material currently explicitly recognized and listed as being in the multilateral system is ex situ and in collections hosted by national and international public agricultural research and development organizations.

New legally enforceable, reporting and benefitsharing conditions under the ITPGRFA/ multilateral system

The main commitment on the part of the collection holders is similar under the RBC and multilateral system-namely, to make the material available to anyone for agricultural research. The responsibilities under which material was supposed to be conserved and distributed were, however, much less concretely defined under the RBC. Each organization holding $\mathrm{RBC}$ material agreed, through an exchange of letters with the IBPGR, to the following conditions. Genebanks holding base collections had to guarantee the availability of the material to the international scientific community and store the materials under appropriate conditions to preserve viability for long periods. All of the materials in the base collections were duplicated for safety, using appropriate monitoring and regeneration regimes to safeguard the long-term maintenance of the collection. The genebanks were required to continue to provide adequate operating funds and personnel to maintain the collections, and if this would not be possible at some future point, the FAO/IBPGR would be alerted.

Very little else in terms of the definition of the rights or responsibilities of the collection hosts/holders under the RBC can be verified from the available records. It is important to note that no common instruments (for example, material transfer agreements) were developed for use by the collection holders in execution of their undertakings as part of the RBC. No benefit-sharing conditions were required for users, and there were no obligations to report on the status of the materials in the collections or on the transfers of samples of those materials to others.

Under the ITPGRFA, the terms and conditions are much more exhaustively defined and 'legalized' under the multilateral system, including mandatory benefit sharing and an international infrastructure for documenting of the collections and the distributions of materials. The Contracting Parties of the ITPGRFA have undertaken to provide facilitated access, 'for the purpose of utilization and conservation for research, breeding and training for food and agriculture, provided that such purpose does not include chemical, pharmaceutical and/or other non-food/feed industrial uses' (Article 12.3.a of the ITPGRFA). They agree that the transfer of all materials in the multilateral system will be subject to the SMTA that was adopted by the ITPGRFA's Governing Body in 2006. Among other things, the SMTA includes obligations for recipients to share monetary benefits derived from the commercialization of new 'PGRFA products' that incorporate materials accessed from the multilateral system (Article 6.7 of the SMTA).

Status of RBC materials vis-à-vis the multilateral system

The RBC includes 41 national genebanks, of which 38 are located in countries that have ratified the ITPGRFA (see Table 3 and Online Resource 4). Of these 38 genebanks, 17 have been the subject of member states' notification to the Secretariat/Governing Body, confirming they are included in the multilateral system. Furthermore, the RBC includes 11 
Table 3 Distribution of samples to RBC genebanks and their status vis-à-vis the multilateral system

\begin{tabular}{|c|c|c|c|c|}
\hline & $\begin{array}{l}\text { Number } \\
\text { of } \\
\text { genebanks }\end{array}$ & $\begin{array}{l}\text { Number of RBC } \\
\text { accessions that } \\
\text { belong to Annex } 1 \\
\text { genera }\end{array}$ & $\begin{array}{l}\text { Number of RBC } \\
\text { accessions that } \\
\text { belong to non- } \\
\text { Annex } 1 \text { genera }\end{array}$ & $\begin{array}{l}\text { Number of RBC accessions, } \\
\text { included as part of Article } 15 \\
\text { (that is, Annex } 1 \text { and non-Annex } \\
1 \text { genera) }\end{array}$ \\
\hline $\begin{array}{l}\text { International agricultural research } \\
\text { centres ( } 8 \text { CGIAR centres, CATIE, } \\
\text { CRU, AVRDC) }\end{array}$ & 11 & & & 54,702 \\
\hline $\begin{array}{l}\text { RBC genebanks in ITPGRFA member } \\
\text { states that have provided the ITPGRFA } \\
\text { Secretariat with information regarding } \\
\text { collections of the respective RBC } \\
\text { genera received from IBPGR that are in } \\
\text { the multilateral system }\end{array}$ & 18 & 63,179 & 14,111 & \\
\hline $\begin{array}{l}\text { RBC genebanks in the ITPGRFA } \\
\text { member states that have not provided } \\
\text { the ITPGRFA Secretariat with } \\
\text { information on any collections that are } \\
\text { in the multilateral system or whose } \\
\text { notification of information to the } \\
\text { ITPGRFA Secretariat does not include } \\
\text { the RBC genera }\end{array}$ & 20 & 3,428 & 6219 & \\
\hline $\begin{array}{l}\text { RBC genebanks in non-ITPGRFA } \\
\text { member state }\end{array}$ & 3 & 1450 & 1067 & \\
\hline Total & 52 & 68,057 & 21,397 & 54,702 \\
\hline
\end{tabular}

genebanks hosted by 11 different international institutions. Ten of those institutions have signed Article 15 agreements with the ITPGRFA's Governing Body to place their ex situ collections under the ITPGRFA's framework. Eight of the 10 are CGIAR centres; the other two are the Centro Agronómico Tropical de Investigación y Enseñanza (CATIE) and the Cocoa collection in Trinidad and Tobago (CRU). The eleventh organization is the Asian Vegetable Research and Development Center (AVRDC, also known today as the World Vegetable Center) located in Taiwan, which cannot sign an Article 15 agreement given the political status of its hosting government. However, the AVRDC has adopted the policy followed by the CGIAR centres of making materials available using the SMTA (as though it had signed an Article 15 agreement).

Ultimately, assuming all of the materials distributed to the RBC genebanks still exist, our findings, in accordance with the probability levels mentioned earlier, are that:

Level 02517 accessions (1.75\%) are conserved in genebanks located in countries that are not member states to the ITPGRFA
Level $1 \quad 20,330$ accessions (14.1\%) are non-Annex 1 materials conserved in genebanks in countries that have ratified the ITPGRFA

Level 23428 accessions (2.4\%) are Annex 1 materials conserved in countries that have ratified the ITPGRFA but have not provided any notification to the Treaty Secretariat, confirming the materials are available in the multilateral system

Level 3 63,179 accessions (43.8\%) are Annex 1 materials conserved in countries that have ratified the ITPGRFA, and the Contracting Parties have published notification that PGRFA of the same crops or forages held by the same RBC-recipient organizations are available in the multilateral system

Level $4 \quad 54,702$ accessions (37.95\%) are conserved in genebanks maintained by international institutions that have signed Article 15 agreements with the Governing Body of the ITPGRFA

For the 45,101 'linked' samples/accessions that we were able to confirm are still being conserved (through the identification of accession numbers), most of them 
(82\%) correspond to a probability Level 3 and 4 . In total, $16 \%$ are non-Annex 1 material corresponding to Level 1.

\section{Discussion}

\section{The RBC materials}

All materials collected by the IBPGR were distributed and conserved through the RBC with the aim of being freely available for research and breeding. If those materials are now included in the multilateral system, we can say that the basic commitments and objectives of the RBCs have been successfully carried forward under the ITPGRFA framework (subject also to additional desirable reporting and benefit-sharing conditions). Assuming they still exist, there is a high level of probability that approximately $82 \%$ of the RBC materials are currently available through the multilateral system (falling as they do within probability Levels 3 and 4, as reported above). The number of materials that fall under probability Level 3 has recently increased threefold reaching the amount indicated above due to the United States acceding to the ITPGRFA in 2017. As a result, over 500,000 accessions, which are under the management and control of the US Department of Agriculture/Agricultural Research Service's National Plant Germplasm System (NPGS), the organization that holds the RBC collections, are now available in the multilateral system. Samples of accessions from the US genebank system were made available to users worldwide, although without being subject to internationally agreed benefit-sharing conditions, prior to the United States joining the ITPGRFA (Bretting 2007; Heisey and Day Rubenstein 2015).

An additional $2.4 \%$ of the RBC materials, i.e. those accessions included in the aforementioned level 2, are probably already de jure in the multilateral system, but since no information about them has been published, interested recipients may not know that the materials are available with the SMTA. This outcome is due to the fact that Annex 1 PGRFA 'under the management and control of Contracting Parties and in the public domain' are automatically included in the multilateral system, regardless of whether information about them is published anywhere. These $2.4 \%$ of the RBC materials were distributed to national public organizations that comprise part of the centralized national public administrations of the countries concerned. It therefore seems likely that these collections would be considered to be 'under the management and control' of the Contracting Party and 'in the public domain'.

That said, the countries concerned have not yet responded to an invitation from the Treaty's Secretariat (and endorsed by the Governing Body) to inform the Governing Body about the materials in their country that are available in the multilateral system. Many countries worldwide are working extremely slowly through the process of confirming what materials fit this description, and it is possible that the key operative terms 'management and control', 'contracting party', and 'public domain' could be interpreted differently within various countries, leading to uncertainty as to practical coverage of the multilateral system. It is noteworthy that a relatively small proportion of the RBC materials fall within this category when one considers that the majority of Contracting Parties to the ITGPFRA still have not sent notifications to the Secretariat/Governing Body concerning collections that are available in the multilateral system. ${ }^{8}$ This outcome reflects well on the genebanks and countries concerned and on the criteria and decision making of the IBPGR and the FAO when they identified those genebanks and countries as good candidates for participating in the RBC; their actions over the years retroactively confirm their technical capacities and commitments to making PGRFA internationally available.

A further $14 \%$ of RBC materials are samples of crops and forages that are not included in the ITPGRFA's multilateral system (as they are not listed in Annex I) but that were distributed to organizations in countries that are now ITPGRFA Contracting Parties. On the one hand, these materials cannot formally form a part of the multilateral system. However, many of the countries in which these organizations are hosted-and the organizations themselves-have voluntarily adopted the policy of making non-Annex 1 PGRFA that are under their management and control available under the terms and conditions of the ITPGRFA's multilateral system-

\footnotetext{
8 As of 6 December 2017, 40 Contracting Parties (out of a total of 144 Contracting Parties) have sent such notices to the Secretariat/Governing Body. See http://www.fao.org/planttreaty/areas-of-work/the-multilateral-system/collections/en/.
} 
that is to say, using the SMTA. Among the countries/genebanks that received non-Annex $1 \mathrm{RBC}$ materials that have adopted this policy are the Leibniz Institute for Plant Genetics and Crop Plant Research IPK in Germany, the Centre for Genetic Resources CGN in the Netherlands, and the NPGS in the United States. The European Genebank Integrated System's (AEGIS) partnering organizations, with support from national governments, have assembled a distributed European collection of PGRFA, including over 47,000 accessions that are available to anyone around the world under the SMTA. ${ }^{9}$ To date, $25 \%$ of the accessions in the European collection are not part of the multilateral system.

In total, 23 RBC genebanks located in ITPGRFA member states have received samples of non-Annex 1 genera. In the first 10 years of its operation, $4 \%$ of PGRFA reported as being transferred using the SMTA were of non-Annex 1 crops or forages. Only $2 \%$ of the $\mathrm{RBC}$ materials were distributed to organizations that are in countries that have not ratified or acceded to the Treaty. Regarding the linked materials, we have found that nearly half of them are located in 'Article 15 collections' and another 35\% in genebanks that have provided information regarding availability in the multilateral system. As the linking of RBC samples to accession numbers in genebanks requires sufficient and available passport data, these results are not surprising. Given the advanced documentation status in most international collections and the need for genebanks to have a sufficiently developed documentation system that allows them to identify and flag multilateral system accessions, it has been easier to identify accession numbers.

How to move forward?

In this final section, we identify a number of actions for a range of potential actors to ascertain that the $\mathrm{RBC}$ materials are (or are not) still being conserved, what their legal status in the respective genebanks is, and whether they are being made available for agricultural research and breeding through the ITPGRFA's multilateral system. As a first step, it is essential to

\footnotetext{
$\overline{9}$ See 'AEGIS (the European Genebank Integrated System): European Accessions', http://www.ecpgr.cgiar.org/aegis/ european-collection/european-accessions/ last (accessed 3 November 2018).
}

ascertain the status of the outstanding $75 \%$ of materials distributed to genebanks around the world as part of the RBC. This effort will require redoubling the efforts and following the methods the authors piloted to track and 'link' $25 \%$ of the RBC materials. Our survey has shown that passport information for accessions in general is often not comprehensive and that several of the genebanks were not able to confirm if the materials they held were received from the IBPGR/IPGRI as part of the RBC.

We have demonstrated that it is possible to use the original collecting missions' passport data and the RBC distribution records to 'track down' RBC samples to individual genebanks (see Thormann et al. 2015 for details). An interested organization could support national and international genebanks in mapping/ linking their data to the original passport and collecting data to proactively identify more of the RBC materials. Accession numbers should then be communicated to Bioversity International for inclusion in the BCD so that the accession will become retrievable. Ideally, these accessions will have a DOI assigned by the ITPGRFA, as this should become the preferred identifier in the BCD to support the traceability of the RBC material. ${ }^{10}$ Identifying the RBC materials and sharing information about them with the international community would be useful with respect to all of the RBC materials, regardless of whether or not they are Annex 1 or if the country concerned is an ITPGRFA member state or not. Value and uses of the BCD and the identified RBC material have recently also been shown in research on genetic erosion in wild barley and barley landraces (Thormann et al. 2017, 2018). In these studies, data from the BCD was used to trace barley accessions collected in the 1980s and to re-collect new samples from the old collecting sites, to compose a set of accessions from two time points for comparison.

As a next step, once the genebanks (and the countries within which the genebanks are located) confirm that they are conserving Annex 1 RBC materials, they should then go through the process of confirming that those materials are available in the multilateral system (by virtue of being in the 'management and control' of the national government and

\footnotetext{
${ }^{10}$ For more about DOIs minted under the Global Information System of the ITPGRFA, see http://www.fao.org/plant-treaty/ areas-of-work/global-information-system/doi/en/ (accessed 7 December 2017).
} 
in the public domain). For Contracting Parties hosting RBC materials that have not yet notified the ITPGRFA's Secretariat and Governing Body about materials in the multilateral system, the RBC materials should be given a priority examination, given the nature of the original commitment to make these materials available. If, for some reason, it is determined that the RBC materials are not under the management and control of a contracting party and in the public domain, then the genebank and national authorities should work together to ensure that they are voluntarily included. This would be the most efficacious way to promote the continued availability of those materials in ways that are largely consistent with the original undertakings of the host organizations under the RBC. In both cases-automatic or voluntary inclusion-they should publish information about the existence and availability of those materials through the ITPGRFA's website and other information systems that are part of the global information system under the ITPGRFA.

If the RBC materials are non-Annex 1, the genebanks concerned and the relevant national authorities should work to establish the means to make those materials available using the SMTA. The fact that a significant proportion of RBC materials are nonAnnex 1 materials highlights how it has been necessary for the international community to narrow its focus on a more limited range of crops to obtain consensus about standard access and benefit-sharing rules (according to the multilateral system). One day, the scope of Annex 1 may be expanded to include additional crops and forages, or perhaps even all PGRFA. Until that time, it is incumbent upon the organizations and countries that have received RBC materials to make them available through terms of facilitated access and fair and equitable benefit-sharing. Of course, it may be possible to develop systems of expedited, simplified access under national legislation on the Nagoya Protocol, for example. ${ }^{11}$ However, it would be most efficacious for the organizations

\footnotetext{
$\overline{11}$ See Nagoya Protocol on Access and Benefit Sharing and the Fair and Equitable Sharing of Benefits Arising from Their Utilization, 29 October 2012, http://www.cbd.int/abs/text/ (accessed 24 October 2017) art. 10(c): 'In the development and implementation of its access and benefit-sharing legislation or regulatory requirements, each Party shall: [...] (c) Consider the importance of genetic resources for food and agriculture and their special role for food security'.
}

and countries concerned-when it comes to the old RBC collections-to seek to use the SMTA when making these non-Annex 1 materials available. If that is not possible, then some other mechanism and terms and conditions should be developed whereby the materials are made available by the hosting organization on terms as close as possible to those of the Registry of Base Collections, updated to reflect more recent commitments to benefit sharing (ultimately, adopting the SMTA for such purposes would be by far the most practical).

Given the history, as well as international public nature, of the $\mathrm{RBC}$, and the fact that the ITPGRFA/multilateral system carries forward the spirit and purpose of the RBC, one could argue that the FAO, Bioversity International (the successor in title to the IBPGR), the Secretariat and Governing Body of the ITPGRFA, and, possibly, the Global Crop Diversity Trust have an interest in working with the organizations that received $\mathrm{RBC}$ collections and their host governments (including the national focal points for the ITPGRFA) to explore ways to ensure those materials are indeed available in the multilateral system. They could work together to raise awareness about the existence of those collections. They could also provide coordination and technical back up to the genebanks to confirm if some of their materials were originally received as part of the $\mathrm{RBC}$. If it is determined that some of the old RBC materials are at risk (e.g., if the genebank is not able to guarantee long-term conservation) relevant organizations could work together to support the transfer of this material to other locations as has been done in recent years with Hordeum L., Pisum L. and Pennisetum Rich. ex Pers. samples (Thormann et al. 2015). If needs for assistance outweigh available resources, consideration would have to be given to the relative importance of those collections. The international organizations listed above could also assist the genebank and national program concerned to assemble the relevant information and publish it on the ITPGRFA's website and other databases that form part of the global-level information system. They could even go further, supporting the genebanks and national programs concerned to analyse the viability of the materials, support their regeneration if warranted, and their characterization and evaluation through partnerships with the genebanks and national programs concerned. 
Acknowledgements We thank Daniele Manzella and Kent Nnadozie (ITPGRFA Secretariat), and Charlotte Lusty (Global Crop Diversity Trust) for critical revisions. We acknowledge support from the CGIAR Genebank Platform.

\section{Compliance with ethical standards}

Conflict of interest The authors declare that they have no conflict of interest.

Open Access This article is distributed under the terms of the Creative Commons Attribution 4.0 International License (http:// creativecommons.org/licenses/by/4.0/), which permits unrestricted use, distribution, and reproduction in any medium, provided you give appropriate credit to the original author(s) and the source, provide a link to the Creative Commons license, and indicate if changes were made.

\section{References}

Bretting PK (2007) The U.S. National Plant Germplasm System in an era of shifting international norms for germplasm exchange. Acta Hortic 760:55-60. https://doi.org/10. 17660/ActaHortic.2007.760.5

FAO (1983) Report of the conference of FAO. Twenty-second session. Food and Agriculture Organization of the United Nations, Rome

FAO (2009) International Treaty on Plant Genetic Resources for Food and Agriculture. Food and Agriculture Organization of the United Nations, Rome. http://www.planttreaty.org/ texts_en.htm. Accessed 5 Jan 2018

Flores-Palacios X (1998) Contribution to the estimation of countries' interdependence in the area of plant genetic resources. Commission on Genetic Resources for Food and Agriculture, background study paper no. 7, rev. 1. Food and Agriculture Organization of the United Nations, Rome

Frankel OH (1988) Genetic resources: evolutionary and social responsibilities. In: Kloppenburg JR (ed) Seeds and sovereignty: the use and control of plant genetic resources. Duke University Press, Durham, pp 19-46

Frankel OH, Hawkes JG (1975) Genetic resources: the past ten years and the next. In: Frankel OH, Hawkes JG (eds) Crop genetic resources for today and tomorrow. International biological programme 2. Cambridge University Press, Cambridge, pp 1-14

Gaisberger H, Thormann I, Matteis L, Arnaud E (2013) Bioversity collecting mission database website. http:// www.bioversityinternational.org/e-library/databases/ collecting-missions/. Accessed 5 Jan 2017

Galluzzi G, Halewood M, López Noriega I, Vernooy R (2016) Twenty-five years of international exchanges of plant genetic resources facilitated by the CGIAR genebanks: a case study on international interdependence. Biodivers Conserv 25(8):1421-1446

Ghimiray M, Vernooy R (2017) The importance and challenges of crop germplasm interdependence: the case of Bhutan. Food Secur 9:301-310
Halewood M (2010) Governing the management and use of pooled microbial genetic resources: lessons from the global crop commons. Int J Commons 4(1):404-436

Halewood M (2015) International efforts to pool and conserve crop genetic resources in times of radical legal change. In: Cimoli M et al. (eds) Intellectual property rights: legal and economic challenges for development. Oxford University Press, Oxford, pp 288-322

Halewood M, Andrieux E, Crisson L, Rwihaniza Gapusi J, Wasswa Mulumba J, Kouablan Koffi E, Yangzome Dorji T, Raj Bhatta M, Balma D (2013) Implementing mutually supportive access and benefit sharing mechanisms under the plant treaty, convention on biological diversity, and nagoya protocol. Law Environ Dev J 9(1):68-96

Hansen J, Williams JT, Freund R (1984) Institutes conserving crop germplasm: the IBPGR global network of genebanks. IBPGR Secretariat, Rome, p 25

Harlan JR (1975) Our vanishing genetic resources. Science 188:618-621

Heisey P, Day Rubenstein K (2015) Using crop genetic resources to help agriculture adapt to climate change: economics and policy. US Department of Agriculture, Economic Research Service, Washington

IBPGR (1991) Annual report 1990. International Board for Plant Genetic Resources, Rome

ITPGRFA (2015) Opinions and advice of the ad hoc technical advisory committee on the multilateral system and the standard material transfer agreement. Food and Agriculture Organization, Rome

ITPGRFA (2017) Implementation and operations of the multilateral system, Doc IT/GB-7/17/9. Prepared for the seventh session of the governing body of the ITPGRFA. http:// www.fao.org/3/a-mu380e.pdf. Accessed 5 Jan 2017

Khoury CK, Achicanoy HA, Bjorkman AD, Navarro-Racines C, Guarino L, Flores-Palacios X, Engels JMM, Wiersema JH, Dempewolf H, Ramírez-Villegas J, Castañeda-Álvarez NP, Fowler C, Jarvis A, Rieseberg LH, Struik PC (2015) Estimation of countries' interdependence in plant genetic resources provisioning national food supplies and production systems. Research study 8. Food and Agriculture Organization, Rome, p 26

Khoury CK, Achinacoy HA, Bjorkman AD, Navarro-Racines C, Guarino L, Flores-Palacios X, Engels JMM, Wiersema JH, Dempewolf J, Sotelo S, Ramírez-Villegas J, CastañedaÁlvarez NP, Fowler C, Jarvis A, Rieseberg LH, Struik PC (2016) Origins of food crops connects countries worldwide. Proc R Soc B 283:20160792

Kloppenburg J Jr, Kleinman DL (1987) Seed wars: common heritage, private property, and political strategy. Social Rev 95:7-41

Lim E, Halewood M (2008) A short history of the Annex I list. In: Tansey G, Rajotte $\mathrm{T}$ (eds) The future control of food. Earthscan, London, p 249

Mooney P (1983) The law of the seed: another development and plant genetic resources. Dev Dialogue 1-2:1-172

Moore G, Tymowski W (2005) Explanatory guide to the International Treaty on Plant Genetic Resources for Food and Agriculture. International Union for the Conservation of Nature, Gland, p xii +212

Thormann I, Engels JMM (2001) IBPGR/IPGRI register of base collections. In: Development of a scientifically sound and 
financially sustainable global genebank system: Final report on the technical research phase. Annex VII. Systemwide Genetic Resources Program, Rome, Italy

Thormann I, Gaisberger H, Mattei F, Snook L, Arnaud E (2012) Digitization and online availability of original collecting mission data to improve data quality and enhance the conservation and use of plant genetic resources. Genet Resour Crop Evol 59(5):635-644

Thormann I, Fiorino E, Halewood M, Engels JMM (2015) Plant genetic resources collections and associated information as baseline resource for genetic diversity studies: an assessment of the IBPGR supported collections. Genet Resour Crop Evol 62(8):1279-1293

Thormann I, Reeves P, Thumm S, Reilley A, Engels JMM, Biradar CM, Lohwasser U, Börner A, Pillen K, Richards
CM (2017) Genotypic and phenotypic changes in wild barley (Hordeum vulgare subsp. spontaneum) during a period of climate change in Jordan. Genet Resour Crop Evol 64(6):1295-1312

Thormann I, Reeves P, Thumm S, Reilley A, Engels JMM, Biradar CM, Lohwasser U, Börner A, Pillen K, Richards CM (2018) Changes in barley (Hordeum vulgare L. subsp. vulgare) genetic diversity and structure in Jordan over a period of 31 years. Plant Genet Resour Charact Util 16(2):112-126. s1479262117000028

https://doi.org/10.1017/

Visser B (2013) The moving scope of Annex 1: the list of crops covered under the multilateral system. In: Halewood M, López-Noriega I (eds) Crop genetic resources as a global commons. Routledge, Oxon, pp 265-282 